\title{
Effect of Consistent Dividend Payout on Business Value in Nigeria Oil and Gas Sector
}

\author{
Dr. Inyiama Oliver Ikechukwu*, Ubesie Cyril Madubuko \\ Department of Accountancy Enugu State University of Science and Technology, Enugu State, Nigeria \\ inyiamaik@yahoo.com*
}

\begin{abstract}
The aim of this study is to examine the effect of consistent payment of dividend to equity shareholders on the value of the paying company in Nigeria oil and gas sector. A sample of four oil and gas firms listed in Nigeria Stock Exchange from 2002 to 2014 was studied. These companies comprise of Oando Plc, Mobil Oil Nigeria Plc, MRS Nigeria Oil and Conoil Plc. Regression analysis was used to establish the effect of dividend payouts on company value. Dividend Per Share was found to have a positive and significant effect on business value. On causalities, a unidirectional causality was found running from net asset value per share to dividend per share at 1 year and 2 years lagged periods. This implies that the value of a business causes dividend to be paid at a time. A positive correlation was also found between dividend payments and value of a business in Nigeria Oil and Gas sector; though not a strong association. The implication is that an increase in dividend payout propensity gives rise to a proportionate increase in business value. Therefore, companies that desire to increase their value, especially when a sale of such business is contemplated, should endeavor to pay dividends in order to give the right signals to the intended buyers. This will improve the worth of the business when evaluated for investment purposes. However, in order to maintain consistency in dividend payment, earnings is an important factor as it translates into profitability from which dividend is paid. This implies that ultimately, cost-cutting strategies, diversification and integrations are very necessary to improve the revenue generating powers of the firms which by extension, will increase the business value.
\end{abstract}

Keywords: Regression, Dividend, Net Asset, Correlation, Share Price, Oil and Gas.

\section{INTRODUCTION}

Proshare (2016), states that for many investors, dividend paying stocks have come to make a lot of sense in Nigeria, given the cultural belief that making returns on investment is the essence of engaging in any investment or business plan. It further emphasized that many investors think of dividend-paying companies as having low-return investment opportunities compared to high-flying small cap companies whose volatility can be pretty exciting; thus representing dividend-paying stocks as more mature and predictable.

When a company pays a dividend, the company's value may diminish by the amount of the total payout. Investors' reason that the company's stock price should go down by the same amount as the dividend to reflect the company's reduced value. In practice, this doesn't always happen. Dividends affect stock prices, but not always on the payout date. Though dividends are one of the many factors that affect stock prices, demand and forecasts for future profits also have an impact (Johnston, 2015).

Dividend distribution by corporate organizations is a fundamental obligation to shareholders and therefore ranks as one of the most important corporate decisions, as a company's ability to consistently pay out increased levels of dividend over time, conveys information about the management's assessment of the firm's future prospects, thereby sending strong signals to the market about its fundamentals. The investigation towards the revelation of the key determinants of dividend policy, which is regarded as a puzzle, has been on over years. The research works on this subject has no doubt increased our understanding of the concept of dividend policy and its constituents but the puzzle still persists. This could be the justification for the position taken by a school of thought that researchers have merely contributed to the multiple paradoxes of corporate dividend policy, thereby adding more pieces to an enlarged puzzle rather than finding the final matching piece that would provide a more precise and complete understanding of the determinants of dividend policy. 


\section{Dr. Inyiama Oliver Ikechukwu \& Ubesie Cyril Madubuko}

Nwidobie (2013) is of the opinion that the higher these dividends, the satisfied are these owners who see such financial investments as rewarding, and thus attractive to non-owners to invest in; as payment of the reward, dividend, signals good prospects of higher earnings for firms. He stated, while citing Park (2009) that dividend payments are associated with firms with good corporate governance, concluding that firms in legal regimes that focus on protecting investors are more likely to earn more and pay even higher dividends than firms in legal regimes with less investor protection. In terms of shareholders wealth, the conventional wisdom is that a properly managed dividend policy had an impact on share prices and shareholders' wealth (Gill, Biger and Tibrewala, 2010), as efforts are made by management and the board to continually enhance corporate earnings. They further stated that the reasons why dividend should be paid includes that (i) dividends provide certainty about the company's financial wellbeing, (ii) dividends are attractive for investors looking to secure current income, and (iii) dividends help maintain market price of the share. Hence, If ones investing strategy is based around income generation, you may tend to favor companies that issue dividends.

Valuation could be used by financial market participants to determine the price they are willing to pay or receive to effect a sale of a business. Business valuation could be looked at as a process or a set of procedures used to determine what a business is worth. Consequently, business value is really an expected price the business would sell for, assuming it is put up for sale. The real price may vary quite a bit depending on who determines the business value and the parameters considered. The asset approach views the business as a set of assets and liabilities that are used as building blocks to construct the picture of business value. An asset-based approach is a type of business valuation that focuses on a company's net asset value, or the fair-market value of its total assets minus its total liabilities. The asset-based approach basically asks what it would cost to recreate the business. The asset approach is based on the economic principle of substitution. Since every operating business has assets and liabilities, a natural way to address this question is to determine the value of these assets and liabilities. The difference is the business value.

The market approach, as the name implies, relies on signs from the real market place to determine what a business is worth. No business operates in a vacuum. If what you do is really great then chances are there that others are doing the same or similar things. If you are looking at buying a business, you need to decide what type of business you are interested in and then look around to see what the "going rate" is for businesses of that type. The income approach takes a look at the core reason for running a business, which is profitability through cash inflow. Since the money is not in the bank yet, there are some measures of risks of not receiving all or part of it when you expect it. Consequently, in addition to figuring out what kind of money the business is likely to bring, the income valuation approach also factors in the risk content. Since the business value must be established in the present, the expected income and risk must be translated to today.

Arbuckle (2013), states that when a dividend is issued, it causes a decrease in the firm's assets. This is because the dividend is paid out of the company's assets. Usually dividends are paid out in the form of cash, but they can also be paid out in the form of property, such as stocks in another company. Fama (1974) examined the extent to which dividend decisions and investment decisions are related. He found out that dividend and investment decisions of managers are independent. In other words, he emphasized that investments are not a function of the level of dividends paid. A dividend payment also decreases shareholders' equity by an amount equal to the dividend. This is because a dividend payment also decreases retained earnings by the amount of the dividend. This is because retained earnings represent money to be paid to shareholders. Once money is paid out, it is no longer part of the retained earnings. It is important to understand that the reduction in retained earnings and in assets do not represent separate reductions, but represent the same reduction in two different ways (Arbuckle, 2012).

Gill, Biger, and Tibrewala (2010) describe that dividend payout is important for investors because dividends provide certainty about the company's financial well-being, dividends are attractive for investors looking to secure current income, and dividends help maintain market price of the shares. Companies that have a longstanding history of stable dividend payouts would be negatively affected by lowering or omitting dividend distributions. Scottrade (2014) states that if the company declares a dividend payment that's higher or lower than expected, market sentiment may shift causing the stock price to rise or drop accordingly and an expected change in price occurs on the ex-dividend date when the company decreases its market cap by the declared shareholder payout. Management are in a dilemma about whether to pay a large, small or zero percentage of their earnings as dividends or to 
retain them for future investments. This has come about as a result of the need for management to satisfy the various needs of shareholders as well as uncertainty on the effect the dividend payout ratio will have on the market value of their firms (Luvembe, Njangiru and Mungami, 2014).

The study aims at evaluating the interactions, with regards to causality, relationship, magnitude and nature of influence, between dividend per share and net asset value per share in the Nigeria Oil and Gas Sector. The rest of the research paper is organized into four sections as follows: Section 2 reviews existing literature in the area of study, section 3 enlists the methodology, section 4 discusses the empirical results/findings while section 5 concludes after the summary.

\section{REVIEW OF RELATED LITERATURE}

Signaling theory by Ross (1977), who created a theoretical model, had its root from the information asymmetry existing between managers as fund users and shareholders as fund providers. The theory assumes that managers have access to more information relating to the value of the firm's assets than other outside agents and investors. Therefore managers seek to use dividend pay-out policies to signal to the shareholders about the financial performance of their firms. In addition, the firms could also reveal the strategies adopted in pursuing their vision and attaining their mission.

An effort to determine the factors that motivate the dividend policy among the cement industry in Karachi Stock exchange and State bank of Pakistan was made by Islam, Aamir, Ahmad and Saeed (2012). It was found that PE ratio, EPS growth and sale growth are positively associated with the dividend payout while profitability and debt to equity were found to have negative association with dividend payout.

Factors that determine the dividend payout policy in the Lebanese banks listed on the Beirut Stock Exchange which included profitability, liquidity, leverage, firm size, growth, firm risk and previous year's dividend payout, was investigated by Maladjian and Khoury (2014). They used OLS and the dynamic panel regressions and found that the dividend payout policies are positively affected by the firm size, risk and previous year's dividends, but are negatively affected by the opportunity growth and profitability. This implies that firms pay dividends with the intention of reducing the agency conflicts and Lebanese listed firms prefer to invest their earnings to grow rather than to pay more dividends. Arif and Akbar (2013) made an attempt to evaluate profitability, size, tax, investment opportunities and life cycle stage of firm as determinants of dividend policy in non-financial and sub sectors of non-financial sector of Pakistan. Using panel data and regression analysis, it was revealed that profitability, tax, size and investment opportunities are the most influential determinants of dividend policy.

Nuredin (2012) adopted a mixed research approach to conduct a study seeking to find the determinants of dividend policy such as profitability, growth, liquidity, size and leverage of insurance companies in Ethiopia, using panel data and an in-depth interview. The results show that profitability and liquidity positively and significantly influence dividend policy of insurance companies in Ethiopia, whereas growth influences dividend policy negatively and significantly. Size and leverage were found to be insignificant in influencing the dividend policy of insurance companies in Ethiopia.

Exploration into the determinants of the dividend policy in Poland, examining whether corporate governance practices determine the dividend policy in the non-financial companies listed on Warsaw Stock Exchange was done by Kowalewski, Stetsyuk and Talavera (2007). The results suggest that large and more profitable companies have a higher dividend payout ratio. The other ay round, concentrated share ownership as well as the deviation from the one-share-one-vote principle leads to a reduction of the payout dividend ratio, suggesting that dividends may signal the severity of conflicts between controlling owners and minority shareholders. The study found support for the fee cash flow hypothesis implying that dividends in Poland have less of a signaling role than in the developed capital markets.

In an attempt to contribute to solving the dividend puzzle, Moscu (2010) carried out a study to determine the dividend policies for 209 companies listed on London Stock Exchange and Paris Stock Exchange in 2010 and to explain their dividend payment behavior. He estimated some models to examine the impact of firm profitability, return on assets, firm size, previous year's dividend, free cash-flow, total shareholder return, corporate tax, dividend yield and ownership structure on dividend payout ratios. The results show that UK companies pay high dividends if ownership is a more dispersed one and cash from basic activity (free cash flow) is enough to be allocated to equity holders. 


\section{Dr. Inyiama Oliver Ikechukwu \& Ubesie Cyril Madubuko}

In France, the determinants of dividend policy were found to be earnings per share, dividend from the previous year and indebtedness.

An exploration of the determinants of dividend payout ratios for the American service and manufacturing firms was done Gill, Biger and Tibrewala (2010). They found that dividend payout ratio is the function of profit margin, sales growth, debt-to-equity ratio, and tax. However, for firms in the Services industry, the dividend payout ratio is the function of profit margin, sales growth, and debt-to-equity ratio and for manufacturing firms, it was found that dividend payout ratio is the function of profit margin, tax, and market-to-book ratio. The relationship between profitability and dividend payout in Korean banks during $1994-2005$ was examined by Lee (2009) using panel data. He found that the banks with higher profitability or performance pay more dividends and very strong, significant, and consistent evidences that the safer banks pay more dividends.

Lintner (1956) adopted dividend model to examine the dynamics and determinants of dividend payout policy of 320 non financial firms listed in Karachi Stock Exchange. The outcome of the analysis reveals that Pakistani listed non-financial firms depend on both current earning per share and past dividend per share to set their dividend payments. Though, dividend tends to be more sensitive to current earnings than prior dividends. It was also revealed that profitable firms with more stable net earnings can afford larger free cash flows and therefore pay larger dividends, while ownership concentration and market liquidity also have positive impact on dividend payout policy. Investment opportunities and leverage, capitalization and size of the firms exert negative impact on dividend payout policy.

Al-Kuwari (2009) investigated the determinants of dividend policies using a panel dataset of nonfinancial firms listed on the GCC country stock exchanges and a series of random effect Tobit models, impact of government ownership, free cash flow, firm size, growth rate, growth opportunity, business risk, and firm profitability on dividend payout ratios were among the factors considered. It was revealed that the main characteristics of firm dividend payout policy were that dividend payments related strongly and directly to government ownership, firm size and firm profitability, but negatively to the leverage ratio. This implies that firms pay dividends with the intention of reducing the agency problem and maintaining firm reputation, since the legal protection for outside shareholders was limited.

An examination of the determinants among dividend payout of non-financial firms listed on Nairobi Securities Exchange which included profitability, growth, current earnings, liquidity, size and business risk was done by Musiega, Alala, Musiega, Maokomba and Egessa (2013). Using purposive sampling technique for sample selection of 30 non-financial companies and descriptive statistics and multiple regressions for analysis, it was found that return on equity, current earnings and firms' growth activities were positively correlated to dividend payout. Business risk and size were found to be among the major determinants of dividend payout.

An exploration of the determinants of the dividend policy of firms in the Japanese electrical appliances industry was conducted by Tsuji (2010). The research outcome reveals that corporate managers do not cater for investors' demands in both their dividend initiation and continuation decisions. The determinants of firm's dividend policies in the Japanese electrical appliances industry are value-weighted dividend yields, value weighted non-payers' size, and value-weighted after-tax earnings-to-total-asset ratios. It further reveals that dividend payments tend to decrease company earnings in the Japanese electrical appliances industry in contravention of the traditional signaling hypothesis.

Zaman (2013) examined bank profitability, growth, and size by using multiple regression and correlation, as potential determinants of dividend policy in Dhaka Stock Exchange of Bangladesh. The study reveals that while profitability appears to be a better determinant of bank dividend policy than a bank's growth and size, it may not be concluded that profitability alone is a strong indicator of bank dividend policy over time in the capital market of Bangladesh.

An examination of the factors determining dividend represented by Dividends per share for nonfinancial companies in the Saudi Arabia stock exchanges (TASI) was conducted by Alzomaia, and AlKhadhiri (2013) applying regression model and using panel data. The impact of Earnings per share (EPS), Previous Dividends represented by dividends per share for last year, Growth, Debt to Equity (D/E) ratio, Beta and Capital Size on Dividends per Share was considered. It was revealed that Saudi 
listed non-financial firms rely on current earnings per share and past dividend per share of the company to set their dividend payments.

Hellström and Inagambaev (2012) examined the relationship between a number of company selected factors such as free cash flow, growth, leverage, profit, risk and size and the companies' dividend payout ratios, using both an Ordinary least square (OLS) and a Tobit regression. Previous studies were reviewed as well as dividend theories in order to conclude which factors that potentially could have an impact on the companies' dividend payout ratios. The dividend payout ratios of large caps were found to have a significant relationship with free cash flow, growth and risk, while the dividend payout ratios of medium caps have a significant relationship with free cash flow, leverage, risk and size.,

\section{Methodology}

\subsection{Data}

The research was conducted in the petroleum sector of Nigeria with eight companies listed in Nigeria Stock Exchange namely African Petroleum Plc, Afroil Plc, Chevron Oil Nigeria Plc, Conoil Plc, Eterna Oil \& Gas Plc, Mobil Oil Nigeria Plc, Oando Plc and Total Nigeria Plc. Availability of data is key to an ex post research of this nature, hence Mobil, Total and Conoil Company were selected and used for data collection and analysis. Annual data was obtained for earnings per share and dividend per share from the annual report and accounts of the selected companies. Other companies in the sector had scanty information about the variables under consideration.

The research variables were structured into dependent and independent variable for the purpose of analysis. The dependent variable of the study is the value of a business while the independent variable is Dividend Per Share (DPS). The study used simple regression analysis in the form of Ordinary Least Square (OLS) method to test the effect of Dividend Per Share on Business Value of firms in Oil and Gas Sector. The simple regression model shows the dependent variable (Business Value) as a function of a single independent variable, dividend per share, in line with the stated objective of the study. Correlation analysis was employed to determine the extent of association of the variables under study.

$\mathrm{BVti}=\beta \mathrm{o}+\beta 1$ DPSt $-1 \mathrm{i},+$ et

Where,

$\mathrm{BV}=$ Business Value

DPS $=$ Dividend Per Share

$\beta o=$ Coefficient (constant) to be estimated

$\mathrm{t}=$ Current period

$\mathrm{t}-\mathrm{i}(\mathrm{i}=1)=$ One year lag period

$\mathrm{e}=$ Stochastic disturbance (error) term

The EViews software provides the signs and significance for interpretation of the result for test of regression and correlation analysis. The output from Eviews software tallies with the decision rule that the coefficient is significant if the p-value is equal to or less than 0.05 .

\section{DiscusSION OF FINDINGS}

Table1. Description of Variables

\begin{tabular}{|l|l|l|}
\hline Title & Acronym & Mathematical Representation \\
\hline Dividend Per Share & DPS & Proposed Dividend /Outstanding Shares \\
\hline Net Asset Value Per Share (Business Value) & NAVPS & Net Asset/ Number of Ordinary Shares on issue \\
\hline
\end{tabular}

Source: Author's Arrangement.

The time series data obtained from annual report and accounts of Mobil, Total and Conoil Company were checked for stationarity. If time series data used for analysis are not stationary, it could lead to spurious regression. However, to obtain initial evidence of stationary status before subjecting the data to Unit Root Test, the following graphical representations were made. The outcome as seen in Figure 3 reveals non stationarity status for both variables because the line graphs failed to cross the zero line repeatedly. 


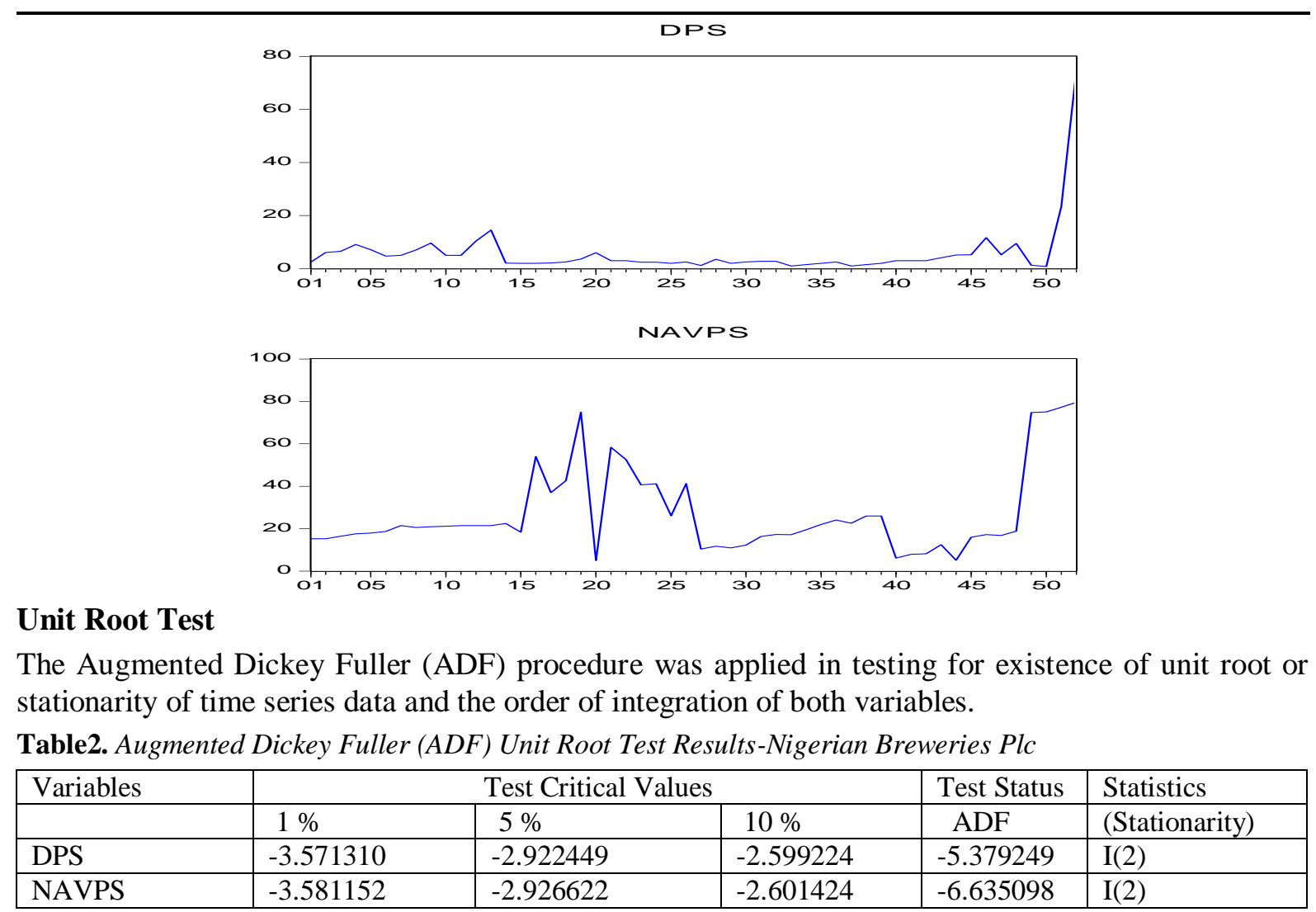

Source: Researcher's EView 8.0 Computation

Tables 2 reveals that the time series data from the companies (Mobil, Total and Conoil Nigeria Plc), under the Augmented Dickey Fuller (ADF) procedure, achieved stationarity at second difference. Hence, when time series data of the variables are integrated of the same order, the data tend to cointegrate (Engle and Granger, 1985). Engle and Granger documents that when two time series data are integrated of the same order and some linear combination of them is stationary, then the two series are cointegrated. The consequences of such cointegration are that;

- Cointegrated series share a stochastic component and a long term equilibrium relationship.

- Deviations from this equilibrium relationship as a result of shocks will be corrected over time.

- We can think of $\triangle \mathrm{NAVPS}_{\mathrm{t}}$ as responding to shocks from DPS over the short and long term.

Therefore the outcome of the unit root tests resulted in the generation of data series, free from unit root as shown in the graphs below:

DDPS
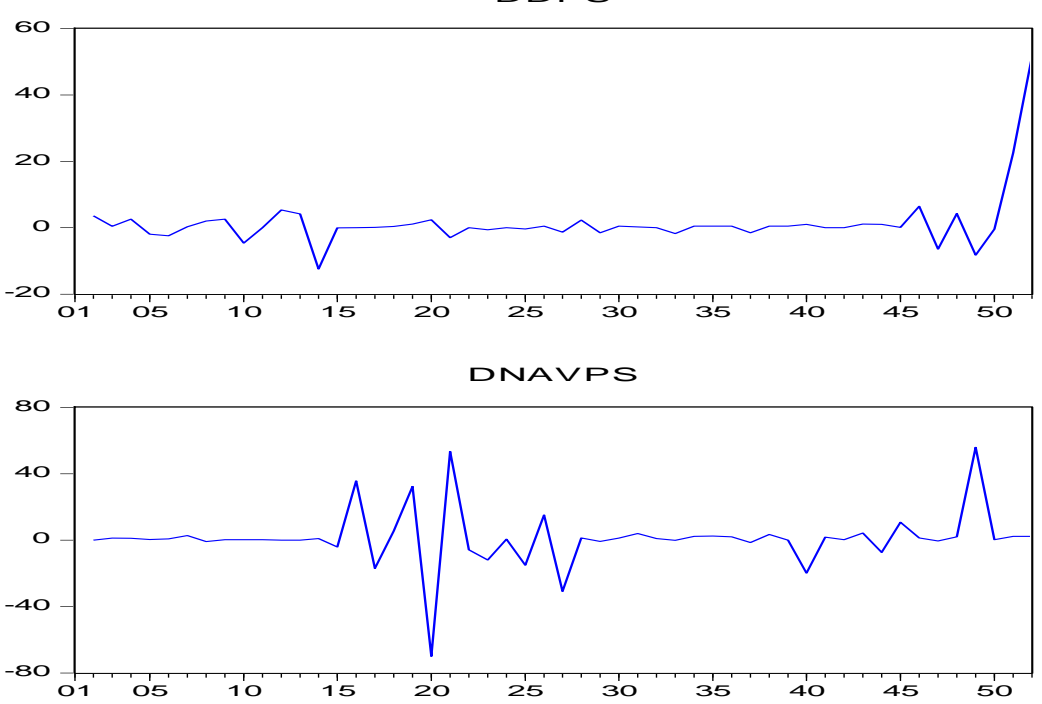

Figure2. Graphical Representation of the Variables after differencing at I(2)

Source: Author's EView 8.0 Output. 
Effect of Consistent Dividend Payout on Business Value in Nigeria Oil and Gas Sector

Table3. Descriptive Statistics

\begin{tabular}{|l|l|l|}
\hline STATISTICS & DPS & NAVPS \\
\hline Mean & 5.852308 & 27.20827 \\
\hline Median & 3.000000 & 20.72500 \\
\hline Maximum & 74.93000 & 79.60000 \\
\hline Minimum & 0.810000 & 4.960000 \\
\hline Std. Dev. & 10.55071 & 20.08085 \\
\hline Skewness & 5.637061 & 1.444671 \\
\hline Kurtosis & 36.90958 & 4.034906 \\
\hline Jarque-Bera & 2766.758 & 20.40856 \\
\hline Probability & 0.000000 & 0.000037 \\
\hline Sum & 304.3200 & 1414.830 \\
\hline Sum Sq. Dev. & 5677.189 & 20565.26 \\
\hline Observations & 52 & 52 \\
\hline
\end{tabular}

Source: Author's EView 8.0 Output.

Table 3 describes the statistics of the study. The coefficient of skewness for DPS ( 5.637061) and NAVPS( 1.444671) have values above One (1) signifying abnormal frequency distribution. Kurtosis coefficient is 36.90958 and 4.034906 for DPS and NAVPS. Jarque-Bera statistic shows that DPS and NAVPS have significant p- values of 0.000000 and 0.000037 respectively. Both Kurtosis and Jarque-Bera statistic confirm that the time series data were not normally distributed. The standard deviations were not volatile as it stood at 10.55071 for DPS and 20.08085 for NAVPS.

Granger-Causality test is conducted in the context of linear regression models and specified in bivariate linear autoregressive model of two variables $X_{1}$ and $X_{2}$ based on lagged values as applied by Pasquale (2006):

$$
\begin{aligned}
& \mathrm{X}_{1}(\mathrm{t}) \sum_{j=1}^{P} \mathrm{~A}_{11, j} \mathrm{X}_{1}(\mathrm{t}-\mathrm{j})+\sum_{\mathrm{j}=1}^{\mathrm{p}} \mathrm{A}_{12, \mathrm{j}} \mathrm{X}_{2}(\mathrm{t}-\mathrm{j})+\mathrm{E}_{1}(\mathrm{t}) \\
& \mathrm{X}_{2}(\mathrm{t}) \underset{\mathrm{j}=1}{\mathrm{P}} \mathrm{P}_{21, \mathrm{j}} \mathrm{X}_{1}(\mathrm{t}-\mathrm{j})+\sum_{\mathrm{j}=1}^{\mathrm{p}} \mathrm{A}_{22, \mathrm{j}} \mathrm{X}_{2}(\mathrm{t}-\mathrm{j})+\mathrm{E}_{2}(\mathrm{t})
\end{aligned}
$$

Where;

$p$ is the maximum number of lagged observations included in the equation, the matrix $A$ contains the coefficients of the equation (i.e., the contributions of each lagged observation to the predicted values of $\mathrm{X}_{1}(t)$ and $\mathrm{X}_{2}(t)$,

$\mathrm{X}_{1}$ is the DPS which is constant while $\mathrm{X}_{2}$ is the NAVPS, and

$E 1$ and $E 2$ are residuals (prediction errors) for each time series data.

\begin{tabular}{|c|c|c|c|}
\hline \multicolumn{4}{|l|}{ Pairwise Granger Causality Tests } \\
\hline \multicolumn{4}{|l|}{ Date: 03/04/16 Time: 04:39 } \\
\hline \multicolumn{4}{|l|}{ Sample: 00010052} \\
\hline \multicolumn{4}{|l|}{ Lags: 2} \\
\hline Null Hypothesis: & Obs & F-Statistic & Prob. \\
\hline NAVPS does not Granger Cause DPS & 50 & 8.69587 & 0.0006 \\
\hline DPS does not Granger Cause NAVPS & & 0.48810 & 0.6170 \\
\hline
\end{tabular}

Table4. Pairwise Granger Causality Tests

\begin{tabular}{|l|l|l|l|}
\hline Date: 03/04/16 Time: 04:41 & \\
\hline Sample: 0001 0052 & & \\
\hline Lags: 1 & Obs & F-Statistic & Prob. \\
\hline Null Hypothesis: & 51 & 15.4306 & 0.0003 \\
\hline NAVPS does not Granger Cause DPS & & 1.37102 & 0.2474 \\
\hline DPS does not Granger Cause NAVPS
\end{tabular}

Table5. Pairwise Granger Causality Tests

Source: EViews 8.0 Output 
On causalities as shown in Table 4 and 5, there is a unidirectional causality running from NAVPS to DPS, both at 1 year and 2 years lagged periods. The implication is that Net Asset Value Per Share granger causes DPS but not vice versa.

Table7. Regression Analysis Result

\begin{tabular}{|c|c|c|c|c|}
\hline \multicolumn{5}{|c|}{ Dependent Variable: DPS } \\
\hline \multicolumn{5}{|c|}{ Method: Least Squares } \\
\hline \multicolumn{5}{|c|}{ Date: $03 / 04 / 16$ Time: 04:44 } \\
\hline \multicolumn{5}{|l|}{ Sample: 00010052} \\
\hline \multicolumn{5}{|c|}{ Included observations: 52} \\
\hline Variable & Coefficient & Std. Error & t-Statistic & Prob. \\
\hline NAVPS & 0.192944 & 0.069113 & 2.791717 & 0.0074 \\
\hline $\mathrm{C}$ & 0.602641 & 2.329194 & 0.258734 & 0.7969 \\
\hline R-squared & 0.134854 & \multicolumn{2}{|c|}{ Mean dependent var } & 5.852308 \\
\hline Adjusted R-squared & 0.117551 & \multicolumn{2}{|c|}{ S.D. dependent var } & 10.55071 \\
\hline S.E. of regression & 9.911205 & \multicolumn{2}{|c|}{ Akaike info criterion } & 7.462911 \\
\hline Sum squared resid & 4911.599 & \multicolumn{2}{|c|}{ Schwarz criterion } & 7.537959 \\
\hline Log likelihood & -192.0357 & \multicolumn{2}{|c|}{ Hannan-Quinn criter. } & 7.491683 \\
\hline F-statistic & 7.793685 & \multirow{2}{*}{\multicolumn{2}{|c|}{ Durbin-Watson stat }} & 0.900891 \\
\hline Prob(F-statistic) & 0.007407 & & & \\
\hline
\end{tabular}

Source: EViews 8.0 Output

Table 7 reveals that Dividend Per Share has a significant positive effect on Net Asset Value Per Share at 5 percent level of significance.

Table8. Correlation Results

\begin{tabular}{|l|l|l|}
\hline & DPS & NAVPS \\
\hline DPS & 1.000000 & \\
\hline NAVPS & 0.367224 & 1.000000 \\
\hline
\end{tabular}

Source: EView 8.0 Computation Output.

Table 8, reveals a positive correlation between net asset value per share and dividend per share in Nigeria Oil and Gas sector. There is a weak and insignificant relationship between net asset value per share and dividend per share at approximately $37 \%$.

\section{SUMMARY AND CONCLUSION}

The study aims at determining the extent to which dividend per share influences the value of a business and the nature and magnitude of their causalities and relationships. Dividend Per Share has a positive and significant effect on Net Asset Value Per Share. On causalities, there is a unidirectional causality running from net asset value per share to dividend per share at 1 year and 2 years lagged periods. There is a positive correlation between net asset value per share and dividend per share in Nigeria Oil and Gas sector; though not too strong. The implication is that net asset value per share granger causes dividend per share but not vice versa.

Consequently, the findings reveal that consistent payment of dividend by companies in the Oil and Gas sector of the Nigeria economy, in line with the dividend signaling theory, increases the value of the companies especially in the long run. This is also in line with the dictates of the life cycle theory. The confidence of the investors receives a boost when dividend is consistently paid as this could be an indication that the paying company is sound in health. This however, attracts more investment that tend to increase the net asset value of the company.

The causality relationship further lends a proof that the value of a company at a point in time causes dividend to be consistently paid. This scenario is justified by the life cycle theory which supports that upon maturity, when a company has harnessed its' investment and growth opportunities, the company can comfortably afford to pay dividends to shareholders that have endured when the company was at the growth stage. On a positive note, the value of a business associates with the dividend payout propensity, meaning that an increase in one could lead to an increase in the other and vice versa.

Therefore, companies that desire to increase their value, especially when a sale of such business is contemplated in the foreseeable future, should endeavor to pay dividends in order to give the right 
signals to the intended buyers. This will improve the worth of the business when evaluated for investment purposes. However, in order to maintain consistency in dividend payment, earnings is an important factor as it translates into profitability from which the dividend is paid. This implies that cost-cutting strategies, diversification and integrations are very necessary to improve earning/revenue of the firms and by extension, the business value.

\section{REFERENCES}

Abraham, W.T.(2013). "Stock Market Reaction to Selected Macroeconomic Variables in the Nigerian Economy", CBN Journal of Applied Statistics 2(1), $61-70$.

Abubakar, J. and Umar, A. (2013). Crude Oil Prices and Foreign Exchange Rates: Evidence of Cointegration and Causality from Nigeria

Adebisi T. (2012).A Vector Autoregressive Analysis of Oil and Exchange Rate in Nigeria: A Case of Dutch Disease, British Journal of Arts and Social Sciences, 11(I). http://www.bjournal.co.uk/ BJASS.aspx

Al-Kuwari, D 2009, „Determinants of the Dividend Policy in Emerging Stock Exchanges: The Case of GCC Countries"e, Global Economy \& Finance Journal, 2(2). 38-63.

Alzomaia, M. and Al-Khadhiri, A. (2013). Determination of Dividend Policy: The Evidence from Saudi Arabia, International Journal of Business and Social Science 4(1).

Dickey, D. A. and Fuller, W. A. (1979). "Distributions of the Estimators for Autoregressive Time Series with a Unit Root". Journal of the American Statistical Association, 74, 423-431.

Engle, R.F., and Granger, C.W.J. (1987). "Cointegration and Error Correction Representation, Estimation and Testing", Econometrica, 255-276

Gill, A., Biger, N. and Tibrewala, R. (2010). Determinants of Dividend Payout Ratios: Evidence from United Statese, The Open Business Journal, 3, 8-14

Granger, C. W. J.(1986), Developments in the Study of Cointegrated Economic Variables, Oxford Bulletin of Economics and Statistics 48, 213-27.

Hellström, G and Inagambaev, G. (2012). Determinants of Dividend Payout Ratios A Study of Swedish Large and Medium Caps, Umeå School of Business and Economics.

Islam, T., Aamir, M., Ahmad, A. and Saeed, M. (2012). Determinants and Motivators of dividend Policy: A Study of Cement Industry of Pakistan, Mediterranean Journal of Social Sciences 3(2), 103-108.

Kowaleski, O., Stetsyuk, I. and Talavera, O. (2007). Corporate Governance and Dividend Policy in Poland"e, Wharton Financial Institutions Centre Working Paper No. 07-09.

Lee, S. W. (2006). Determinants of dividend policy in Korean banking industry"e, Banks and Bank Systems, 4, 67-71.

Lintner, J. (1956). "Distribution of incomes of corporations among dividends, retained earnings, and taxes"e, American Economic Review, 61, 97-113.

Maladjian, C. and El Khoury, R. (2014). Determinants of the Dividend Policy: An Empirical Study on the Lebanese Listed Banks, International Journal of Economics and Finance; 6(4); 240-256

Mlonzi, V.F., Kruger, J. and Nthoesane, M.G. (2011). "Share price reaction to earnings announcement on the JSE-ALtX: A test for market efficiency”, Southern African Business Review, (15), 3.

Moscu, R. (2010). Determinant Agents Analysis of Dividend PoliciesPracticed by Companies Listed in Great Britain and France, Revista Română de Statistică Trim I/2012- Supliment Mueller, D. C. (1972). A Life Cycle Theory of the Firme", Journal of Industrial Economics', 20(3), 199-219.

Musiega, M.G., Alala, O.B., Musiega, D., Maokomba, O. C., and Egessa, R. (2013). Determinants Of Dividend Payout Policy Among Non-Financial Firms On Nairobi Securities Exchange, Kenya, International Journal Of Scientific \& Technology Research, 2(10), 253-266.

Nuredin, M., (2012). Determinants of Dividend Policy of Insurance Companies in Ethiopia, A thesis Submitted to the Department of Accounting and Finance in partial fulfilment of the requirements for the Degree of Master of Science (Accounting and Finance) Addis Ababa University, Ethiopia.

Nwidobie, B. M. (2013). Agency Conflict And Corporate Dividend Policy Decisions In Nigeria, Asian Economic and Financial Review, 3(8):1110-1121 
Park, J.J., (2009). Shareholder compensation as dividend. Michigan Law Review, 108: 323-371. Available from www.michiganlawreview.org.

Pasquale, F. (2006). "Testing for granger causality between stock prices and economic growth". MPRA Paper 2962, University Library of Munich, Germany, revised 2007.

Rao, B.B. (2005). "Estimating Short and Long Run Relationships: A Guide to the Applied Economist". Methodological Issues (May), 1 - 28. Available online at http://129.3.20.41/econwp/em/papers/0508/0508013.pdf

Ross, S. A. (1977). "The determination of financial structure: the incentive-signalling approach", Bell Journal of Economics, 8, 23-40.

Segal, U and Spivak, A.(1985). Firm Size and Optimal Growth Rates, UCLA Working Paper 380, http://www.econ.ucla.edu/workingpapers/wp380.pdf.

Tsuji, C. (2010). What Are The Determinants Of Dividend Policy? The Case Of The Japanese Electrical Appliances Industry, Business and Economics Journal, 9, 1-16. 